\title{
Quantitative Structure-activity Relationships of Herbicidal $N$-(1-Methyl-1-phenylethyl)phenylacetamides*
}

\author{
Osamu Kirino, Chiyozo Takayama and Akihiko Mine \\ Pesticide Research Laboratory, Takarazuka Research Center, Sumitomo Chemical Co., Ltd., \\ Takatsukasa, Takarazuka 665, Japan
}

(Received May 28, 1986)

\begin{abstract}
$N$-(1-Methyl-1-phenylethyl)phenylacetamides exhibited strong growth-inhibiting activity against bulrush, Scirpus juncoides, and barnyard grass, Echinochloa crus-galli, in the vial tests. The phenylacetyl group was essential for the high activity against $S$. juncoides. Structure-activity relationships of $N$-(1-methyl-1-phenylethyl)phenylacetamides having various benzene ring substituents in the acid and amine moieties were analyzed with substituent parameters and regression techniques. The variation in the activity of 83 compounds was related parabolically with the hydrophobicity of the substituents. The steric factor was also important for the activity: it increased with a decrease in length of the 4-substituents in the acid moiety. Electron-withdrawing effect of the substituents at the 3- or 4-position in the amine moiety increased the activity, too. A similar equation was obtained against E. crus-galli. The growth-inhibiting activity was highly correlated with the herbicidal activity in the pot tests.
\end{abstract}

\section{INTRODUCTION}

Our previous papers reported that $\mathrm{N}$ benzylbutanamides like $N$-(1-methyl-1-phenylethyl)-2-bromo-3,3-dimethylbutanamide, bromobutide, exhibit potent herbicidal activity against a wide variety of weeds including perennial weeds. ${ }^{1,2)}$ The quantitative structureactivity relationships of these compounds were analyzed with substituent parameters and regression techniques..$^{3-6)}$

This paper reports that $N$-benzylphenylacetamides such as $N$-[1-methyl-1-(3-chlorophenyl)ethyl]-2-fluorophenylacetamide possess high herbicidal activity. $N$-(1-Methyl-1phenylethyl)phenylacetamides having various benzene ring substituents in the acid and amine moieties were synthesized and tested for their growth-inhibiting activity against Scirpus juncoides and Echinochloa crus-galli in the vial

* Herbicidal Activity of $N$-Benzylbutanamides (Part 8). For Part 7, see Ref. 6). tests. The effect of hydrophobicity of the molecule, the steric dimension of the substituents in the acid moiety and the electronic effect of the substituents in the amine moiety were examined by the Hansch-Fujita method. ${ }^{\text {) }}$ Relationships between the growth-inhibiting activity and the herbicidal activity shown in the pot tests under paddy conditions are also discussed.

\section{MATERIALS AND METHODS}

\section{Compounds}

The structure of the compounds was confirmed by PMR and IR spectroscopy in addition to the elemental analyses for $\mathrm{C}, \mathrm{H}, \mathrm{N}$, and halogens within $\pm 0.30 \%$ of the theoretical values for $\mathrm{C}, \mathrm{H}$, and $\mathrm{N}$ and $\pm 0.45 \%$ for halogens. All melting points are uncorrected. All $N$-(1-methyl-1-phenylethyl) phenylacetamides were prepared by the reaction of the appropriate phenylacetyl chloride with a 1methyl-1-phenylethylamine in the presence of a base. The 1-methyl-1-phenylethylamines 
were obtained by the Hofmann reaction of corresponding carboxylic amides. ${ }^{8,9)}$ A typical procedure is shown below.

$N$-[1-Methyl-1-(3-chlorophenyl)ethyl]-2-fluorophenylacetamide (78): 2-Fluorophenylacetyl chloride $(6.9 \mathrm{~g}, 0.04 \mathrm{~mol})$ was added to a mixture containing 1-methyl-1-(3-chlorophenyl)ethylamine $(6.8 \mathrm{~g}, 0.04 \mathrm{~mol})$, triethylamine $(5.1 \mathrm{~g}$, $0.05 \mathrm{~mol})$ and benzene $(200 \mathrm{ml})$ under stirring at room temperature. After $4 \mathrm{hr}$, the reaction mixture was washed successively with water and dilute $\mathrm{HCl}$. The organic layer, after drying with anhydrous sodium sulfate, was evaporated to dryness and the residue was recrystallized from ethanol to give $9.7 \mathrm{~g}(80 \%)$ of colorless crystals, mp $115-116^{\circ} \mathrm{C}$.

\section{Biological Tests}

The growth-inhibiting activity in the vial tests and the herbicidal activity in the pot tests against bulrush, $S$. juncoides and barnyard grass, E. crus-galli were determined according to the method reported previously. ${ }^{1)}$ The growth-inhibiting activity was expressed as the $\mathrm{pI}_{50}$, negative logarithm of the molar concentration in the test solution required for the $50 \%$ inhibition of the shoot elongation after 12 days cultivation. The herbicidal activity was expressed as the $\mathrm{pED}_{50}$, negative logarithm of the molar dosage per pot required for the $50 \%$ inhibition of the shoot elongation after 3 weeks cultivation.

\section{RESULTS AND DISCUSSION}

\section{Growth-inhibiting Activity}

As shown in Table 1 , the phenylacetyl derivative (2) exhibits high growth-inhibiting activity against $S$. juncoides in the vial test but benzoyl (1), 3-phenylpropionyl (8) and 4-phenylbutanoyl (11) derivatives show low activity. Alkyl substitutions at the $\alpha$-position of the phenylacetyl group (compounds 3-7) also decreased the activity. Dimethyl substitutions at the $\alpha$ - or $\beta$-position of the 3-phenylpropionyl group (compounds 9 and 10) were slightly effective to increase the activity of the unsubstituted compound but their activity was weaker than that of the phenylacetyl derivative. These results may strongly indicate that the phenylacetyl group has the optimum structure as the acid moiety.
Table $1 \quad N$-(1-Methyl-1-phenylethyl)phenyl substituted-acetamides and their growth-inhibiting activity against Scirpus juncoides.

\begin{tabular}{|c|c|c|c|}
\hline No. & $\mathrm{R}$ & $\mathrm{mp}\left({ }^{\circ} \mathrm{C}\right)$ & $\mathrm{pI}_{50}$ \\
\hline $\mathbf{1}$ & $\mathrm{Ph}$ & $163-164$ & 2.70 \\
\hline 2 & $\mathrm{PhCH}_{2}$ & $132-133.5^{\mathrm{a}, \mathrm{b}}$ & 5.70 \\
\hline 3 & $\mathrm{Ph}(\mathrm{Me}) \mathrm{CH}$ & $114.5-116$ & 5.43 \\
\hline 4 & $\mathrm{Ph}(\mathrm{E} t) \mathrm{CH}$ & $109.5-111$ & 5.22 \\
\hline 5 & $\mathrm{Ph}(i-\mathrm{Pr}) \mathrm{CH}$ & $154-155$ & $<3.7$ \\
\hline 6 & $\mathrm{Ph}(\mathrm{Me})_{2} \mathrm{C}$ & $113-115$ & 5.22 \\
\hline 7 & $\mathrm{Ph}(\mathrm{Et})_{2} \mathrm{C}$ & $111-112.5$ & 4.91 \\
\hline 8 & $\mathrm{PhCH}_{2} \mathrm{CH}_{2}$ & $96-98$ & 4.52 \\
\hline 9 & $\mathrm{Ph}(\mathrm{Me})_{2} \mathrm{CCH}_{2}$ & $94-95$ & 5.32 \\
\hline 10 & $\mathrm{PhCH}_{2}(\mathrm{Me})_{2} \mathrm{C}$ & $101-102.5$ & 5.02 \\
\hline 11 & $\mathrm{PhCH}_{2} \mathrm{CH}_{2} \mathrm{CH}_{2}$ & $60.5-62$ & 4.55 \\
\hline
\end{tabular}

a) Lit. value: $132-132.7^{\circ} \mathrm{C}$ (T. Takematsu et al. Jpn. Pat. Kokai Sho-55-104240).

b) Lit. value: $132-133^{\circ} \mathrm{C}(\mathrm{H}$. Takahashi \& $\mathrm{T}$. Suzuki: Jpn. Pat. Kokai Sho-57-139052).

\section{Structure-activity Correlation}

As shown in Table 2, the growth-inhibiting activity of $N$-(1-methyl-1-phenylethyl)phenylacetamides against $S$. juncoides and $E$. crusgalli varies considerably with the variation of the benzene ring substituents. The results were quantitatively analyzed by the HanschFujita method ${ }^{\text {) }}$ using substituent parameters listed in Table 3.

Changes in steric dimensions of the 4-substituents of the benzene ring in the acid moiety cause considerable variation in activity. The activity of $\mathrm{N}$-(1-methyl-1-phenylethyl)-monosubstituted-phenylacetamides (compounds 2 and 12-30) against $S$. juncoides was roughly represented by Eq. (1) in Table 4 with only the STERIMOL length parameter ${ }^{10)}$ for the 4 -substituents, $L_{4 x}$. No significant correlation was derived from other steric parameters such as Taft's steric parameter, $E_{\mathrm{s}},{ }^{11)}$ van der Waals volume, $V_{\mathrm{w}}{ }^{12)}$ or molar refractivity, MR. ${ }^{13)}$ Adding hydrophobic $\pi^{2}$ and $\pi$ terms to Eq. (1) to yield Eq. (2) significantly improved the correlation $\left(F_{2,16}=7.62 ; F_{2,16,0.005}=7.51\right)$. The $\pi$ values from the benzene system ${ }^{14)}$ were used in Eq. (2) because they were slightly superior to those from the phenylacetic acid system and 
Table $2 \quad N$-(1-Methyl-1-phenylethyl)phenylacetamides and their growth-inhibiting and herbicidal activities against Scirpus juncoides and Echinochloa crus-galli.

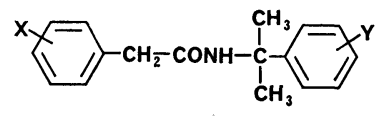

\begin{tabular}{|c|c|c|c|c|c|c|c|c|c|}
\hline \multirow{3}{*}{ No. } & \multirow{3}{*}{$\mathrm{X}$} & \multirow{3}{*}{$\mathrm{Y}$} & \multirow{3}{*}{$\mathrm{mp}\left({ }^{\circ} \mathrm{C}\right)$} & \multicolumn{4}{|c|}{$\mathrm{pI}_{50}$} & \multicolumn{2}{|c|}{$\mathrm{pED}_{50}$} \\
\hline & & & & \multicolumn{2}{|c|}{ S. juncoides } & \multicolumn{2}{|c|}{ E. crus-galli } & \multirow{2}{*}{$\begin{array}{c}\text { S. } \\
\frac{\text { juncoides }}{\text { Obsd. }}\end{array}$} & \multirow{2}{*}{$\begin{array}{c}\begin{array}{c}\text { E. crus- } \\
\text { galli }\end{array} \\
\text { Obsd. }\end{array}$} \\
\hline & & & & Obsd. & Calcd. $\left.{ }^{a}\right)$ & Obsd. & Calcd. ${ }^{\text {b) }}$ & & \\
\hline 2 & $\mathrm{H}$ & $\mathrm{H}$ & $132-133.5$ & 5.70 & 5.39 & 4.95 & 4.81 & 5.6 & 5.3 \\
\hline 12 & 2-Me & $\mathrm{H}$ & $\left.132-134^{c}\right)$ & 5.43 & 5.72 & 5.15 & 5.16 & 5.4 & 5.2 \\
\hline 13 & $2-i-\operatorname{Pr}$ & $\mathrm{H}$ & $\left.78-81^{d}\right)$ & 5.29 & 5.76 & 4.67 & 5.07 & 5.0 & 4.8 \\
\hline 14 & $2-\mathrm{F}$ & $\mathrm{H}$ & $139-140$ & 5.78 & 5.49 & 5.39 & 4.93 & 5.4 & 5.4 \\
\hline 15 & $2-\mathrm{Cl}$ & $\mathrm{H}$ & $142-143^{\mathrm{e}, \mathrm{n})}$ & 5.76 & 5.77 & 5.28 & 5.20 & 5.4 & 5.3 \\
\hline 16 & 2-OMe & $\mathrm{H}$ & $127.5-129^{f)}$ & 5.45 & 5.37 & 5.05 & 4.80 & 5.2 & 5.2 \\
\hline 17 & $2-\mathrm{NO}_{2}$ & $\mathrm{H}$ & $152-154^{\mathrm{g})}$ & 5.15 & 5.13 & 4.28 & 4.54 & 5.0 & 4.5 \\
\hline 18 & 3-Me & $\mathrm{H}$ & $99.5-101.5$ & 5.58 & 5.72 & 5.15 & 5.16 & 5.1 & 5.4 \\
\hline 19 & $3-\mathrm{F}$ & $\mathrm{H}$ & $114-115$ & 5.58 & 5.49 & 5.15 & 4.93 & 5.2 & 5.3 \\
\hline 20 & $3-\mathrm{Cl}$ & $\mathrm{H}$ & $111-113^{\mathrm{h}, \mathrm{o})}$ & 5.58 & 5.77 & 5.16 & 5.20 & 5.1 & 5.1 \\
\hline 21 & $3-\mathrm{CF}_{3}$ & $\mathrm{H}$ & $\left.86-88^{i}\right)$ & 5.53 & 5.81 & 5.01 & 5.22 & 5.3 & 4.7 \\
\hline 22 & 3-OMe & $\mathrm{H}$ & $102-103.5$ & 5.45 & 5.37 & 4.82 & 4.80 & 5.5 & 4.9 \\
\hline 23 & $3-\mathrm{NO}_{2}$ & $\mathrm{H}$ & $116-117.5$ & 4.67 & 5.13 & 4.28 & 4.54 & 5.0 & 4.8 \\
\hline 24 & 4-Me & $\mathrm{H}$ & $133-134.5$ & 5.43 & 5.26 & 5.03 & 4.80 & 5.3 & 4.9 \\
\hline 25 & $4-i-\operatorname{Pr}$ & $\mathrm{H}$ & $104.5-106$ & 4.71 & 4.75 & 4.17 & 4.29 & 4.7 & 4.7 \\
\hline 26 & $4-F$ & $\mathrm{H}$ & $\left.125.5-127^{j}\right)$ & 5.43 & 5.20 & 4.59 & 4.70 & 5.1 & 4.5 \\
\hline 27 & $4-\mathrm{Cl}$ & $\mathrm{H}$ & $128-130^{\mathrm{k})}$ & 5.46 & 5.06 & 4.76 & 4.64 & 5.3 & 4.7 \\
\hline 28 & $4-\mathrm{Br}$ & $\mathrm{H}$ & $123.5-125.5$ & 4.81 & 4.94 & 4.32 & 4.54 & 4.6 & 4.3 \\
\hline 29 & 4-OMe & $\mathrm{H}$ & $123-124^{1)}$ & 4.27 & 4.43 & 4.05 & 4.06 & 4.7 & 4.4 \\
\hline 30 & 4-OEt & $\mathrm{H}$ & $111-113$ & 4.27 & 4.24 & 4.17 & 3.98 & 4.4 & 4.0 \\
\hline 31 & $2,5-\mathrm{Me}_{2}$ & $\mathrm{H}$ & $151.5-152.5$ & $\left.5.09^{s}\right)$ & 5.82 & $4.15^{s)}$ & 5.22 & $5.1^{\mathrm{s})}$ & $5.1^{s)}$ \\
\hline 32 & $2,4-\mathrm{Cl}_{2}$ & $\mathrm{H}$ & $161.5-163$ & $4.94^{\mathrm{s})}$ & 5.07 & $4.28 \mathrm{~s})$ & 4.57 & $4.5^{s)}$ & $4.5^{s)}$ \\
\hline 33 & $3,4-\mathrm{OMe}_{2}$ & $\mathrm{H}$ & $106.5-107.5$ & $3.50^{\mathrm{s})}$ & 4.41 & $3.62^{s)}$ & 4.04 & $4.1^{s)}$ & $4.0^{\mathrm{s})}$ \\
\hline 34 & $\mathrm{H}$ & 2-Me & $130-132$ & 5.55 & 5.72 & 5.03 & 5.16 & 5.0 & 5.1 \\
\hline 35 & $\mathrm{H}$ & 2-Cl & $109.5-110.5$ & 5.60 & 5.77 & 5.01 & 5.20 & 5.2 & 5.4 \\
\hline 36 & $\mathrm{H}$ & $3-\mathrm{Me}$ & $120.5-122$ & 5.74 & 5.71 & 5.13 & 5.15 & 5.4 & 5.1 \\
\hline 37 & $\mathrm{H}$ & $3-\mathrm{F}$ & $141-143$ & 6.52 & 6.42 & 5.45 & 5.47 & 5.4 & 5.0 \\
\hline 38 & $\mathrm{H}$ & $3-\mathrm{Cl}$ & $114-115$ & 6.66 & 6.58 & 5.74 & 5.67 & 5.5 & 5.3 \\
\hline 39 & $\mathrm{H}$ & $3-\mathrm{Br}$ & $108-109$ & 6.42 & 6.61 & 5.42 & 5.70 & 5.6 & 5.5 \\
\hline 40 & $\mathrm{H}$ & 4-Me & $132-133$ & 6.03 & 5.71 & 5.43 & 5.15 & 5.4 & 5.0 \\
\hline 41 & $\mathrm{H}$ & 4-Et & $116-120$ & 5.96 & 5.81 & 4.85 & 5.22 & 5.0 & 4.6 \\
\hline 42 & $\mathrm{H}$ & $4-i-\operatorname{Pr}$ & $157-158.5$ & 5.57 & 5.74 & 4.51 & 5.07 & 4.6 & 4.3 \\
\hline 43 & $\mathrm{H}$ & $4-F$ & $129.5-131$ & 6.43 & 6.34 & 5.27 & 5.21 & 5.2 & 4.9 \\
\hline 44 & $\mathrm{H}$ & $4-\mathrm{Cl}$ & $139-140$ & 6.20 & 6.51 & 5.38 & 5.45 & 5.4 & 5.3 \\
\hline 45 & $\mathrm{H}$ & 4-Br & $162-163$ & 6.24 & 6.54 & 5.14 & 5.47 & 5.3 & 5.0 \\
\hline 46 & $\mathrm{H}$ & 4-OMe & $110.5-112$ & 5.65 & 5.84 & 4.65 & 4.96 & 5.2 & 5.2 \\
\hline 47 & $\mathrm{H}$ & $2,5-\mathrm{Me}_{2}$ & $166-168$ & $5.20^{\mathrm{s})}$ & 5.81 & $4.91^{\mathrm{s})}$ & 5.21 & $4.8^{s)}$ & $5.0^{\mathrm{s})}$ \\
\hline 48 & $\mathrm{H}$ & $2,4-\mathrm{Cl}_{2}$ & $117.5-119$ & $5.60^{\mathrm{s})}$ & 6.52 & $5.00^{s)}$ & 5.37 & $4.9^{s)}$ & $5.2^{s)}$ \\
\hline 49 & $\mathrm{H}$ & $2,6-\mathrm{Cl}_{2}$ & $151-152$ & $4.11^{s)}$ & 5.79 & $3.95^{\mathrm{s})}$ & 5.13 & $4.3^{s)}$ & $4.0^{s)}$ \\
\hline 50 & $\mathrm{H}$ & $3,4-\mathrm{Cl}_{2}$ & $134-135$ & $6.29^{\mathrm{s})}$ & 7.33 & $5.60^{s)}$ & 5.85 & $5.3^{s)}$ & $5.0^{\mathrm{s})}$ \\
\hline 51 & 2-Me & 2-Me & $127-128.5$ & 5.85 & 5.82 & 5.45 & 5.22 & 5.6 & 5.5 \\
\hline 52 & $2-\mathrm{F}$ & 2-Me & $125.5-127$ & 5.68 & 5.77 & 5.22 & 5.20 & 5.6 & 5.1 \\
\hline 53 & $2-\mathrm{Cl}$ & 2-Me & $143-146$ & 5.72 & 5.81 & 5.30 & 5.18 & 5.5 & 5.3 \\
\hline 54 & 2-OMe & 2-Me & $112-113$ & 6.07 & 5.71 & 5.17 & 5.15 & 5.6 & 5.2 \\
\hline 55 & $3-\mathrm{Me}$ & 2-Me & $110.5-111.5$ & 5.89 & 5.82 & 5.30 & 5.22 & 5.6 & 5.5 \\
\hline 56 & $3-\mathrm{Cl}$ & 2-Me & $133-134$ & 6.00 & 5.81 & 5.25 & 5.18 & 5.6 & 5.5 \\
\hline 57 & 2-Me & $2-\mathrm{Cl}$ & $124-125$ & 5.58 & 5.81 & 5.07 & 5.18 & 5.5 & 5.7 \\
\hline 58 & $2-\mathrm{F}$ & $2-\mathrm{Cl}$ & $119-120.5$ & 5.44 & 5.81 & 5.53 & 5.22 & 5.4 & 5.3 \\
\hline
\end{tabular}


Table 2 (Continued).

\begin{tabular}{|c|c|c|c|c|c|c|c|c|c|}
\hline \multirow{3}{*}{ No. } & \multirow{3}{*}{$\mathrm{x}$} & \multirow{3}{*}{$\mathrm{Y}$} & \multirow{3}{*}{$\operatorname{mp}\left({ }^{\circ} \mathrm{C}\right)$} & \multicolumn{4}{|c|}{$\mathrm{pI}_{50}$} & \multicolumn{2}{|c|}{$\mathrm{pED}_{50}$} \\
\hline & & & & \multicolumn{2}{|c|}{ S. juncoides } & \multicolumn{2}{|c|}{ E. crus-galli } & \multirow{2}{*}{$\begin{array}{c}S . \\
\text { juncoides } \\
\text { Obsd. }\end{array}$} & \multirow{2}{*}{$\begin{array}{c}\begin{array}{c}\text { E. crus- } \\
\text { galli }\end{array} \\
\text { Obsd. }\end{array}$} \\
\hline & & & & Obsd. & Calcd. ${ }^{a)}$ & Obsd. & Calcd. ${ }^{b)}$ & & \\
\hline 59 & $2-\mathrm{Cl}$ & $2-\mathrm{Cl}$ & $143-145$ & 5.65 & 5.79 & 5.22 & 5.13 & 5.2 & 5.6 \\
\hline 60 & 2-OMe & $2-\mathrm{Cl}$ & $79.5-81.5$ & 5.46 & 5.77 & 5.05 & 5.19 & 5.1 & 5.1 \\
\hline 61 & $3-\mathrm{Me}$ & $2-\mathrm{Cl}$ & 98-99 & 5.57 & 5.81 & 5.08 & 5.18 & 5.2 & 5.4 \\
\hline 62 & $3-\mathrm{Cl}$ & $2-\mathrm{Cl}$ & $125-127$ & 5.65 & 5.79 & 5.15 & 5.13 & 5.3 & 5.6 \\
\hline 63 & 3-OMe & $2-\mathrm{Cl}$ & 96-97 & 5.42 & 5.77 & 5.12 & 5.19 & 5.1 & 5.1 \\
\hline 64 & $4-\mathrm{Me}$ & $2-\mathrm{Cl}$ & $109-110$ & 5.18 & 5.35 & 5.18 & 4.82 & 5.2 & 5.2 \\
\hline 65 & $4-\mathrm{Cl}$ & $2-\mathrm{Cl}$ & $128-132$ & 5.41 & 5.07 & 5.06 & 4.57 & 4.9 & 4.9 \\
\hline 66 & $2-\mathrm{Me}$ & 3-Me & $103-104$ & 5.79 & 5.81 & 5.17 & 5.21 & 5.4 & 5.4 \\
\hline 67 & $2-\mathrm{F}$ & 3-Me & $112-113$ & 5.92 & 5.75 & 5.41 & 5.19 & 5.8 & 5.5 \\
\hline 68 & $2-\mathrm{Cl}$ & $3-\mathrm{Me}$ & 94-95 & 6.10 & 5.80 & 5.28 & 5.17 & 5.5 & 5.5 \\
\hline 69 & 2-OMe & 3-Me & $73-74.5$ & 5.79 & 5.70 & 5.03 & 5.14 & 5.5 & 5.5 \\
\hline 70 & $3-\mathrm{Me}$ & 3-Me & $95-98$ & 5.82 & 5.81 & 5.19 & 5.21 & 5.5 & 5.4 \\
\hline 71 & $3-\mathrm{Cl}$ & 3-Me & $105-106$ & 6.22 & 5.80 & 5.32 & 5.17 & 5.7 & 5.6 \\
\hline 72 & $3-\mathrm{CF}_{3}$ & 3-Me & $79-82$ & 5.73 & 5.76 & 5.08 & 5.11 & 5.5 & 5.5 \\
\hline 73 & $4-\mathrm{Br}$ & $3-\mathrm{Me}$ & $109-112$ & 4.64 & 4.90 & 4.50 & 4.44 & 4.5 & 4.5 \\
\hline 74 & 4-OEt & 3-Me & $98-100$ & 4.32 & 4.40 & 3.64 & 4.12 & 4.3 & 4.1 \\
\hline 75 & $2-\mathrm{Me}$ & $3-\mathrm{F}$ & $150-151.5$ & 6.47 & 6.69 & 5.56 & 5.74 & 5.9 & 5.7 \\
\hline 76 & $2-\mathrm{Cl}$ & $3-\mathrm{F}$ & $147-148$ & 6.57 & 6.73 & 5.80 & 5.77 & 5.9 & 6.0 \\
\hline 77 & $2-\mathrm{Me}$ & $3-\mathrm{Cl}$ & $132-133.5$ & 6.49 & 6.62 & 5.71 & 5.65 & 5.8 & 6.1 \\
\hline 78 & $2-\mathrm{F}$ & $3-\mathrm{Cl}$ & $115-116$ & 7.04 & 6.61 & 5.88 & 5.70 & 6.1 & 6.3 \\
\hline 79 & $2-\mathrm{Cl}$ & $3-\mathrm{Cl}$ & $125-126.5$ & 6.71 & 6.59 & 5.91 & 5.60 & 6.0 & 6.1 \\
\hline 80 & 2-OMe & $3-\mathrm{Cl}$ & $95-96.5^{p)}$ & 6.53 & 6.57 & 5.60 & 5.67 & 5.8 & 6.0 \\
\hline 81 & $3-\mathrm{Me}$ & $3-\mathrm{Cl}$ & $121-122.5$ & 6.38 & 6.62 & 5.48 & 5.65 & 5.6 & 6.2 \\
\hline 82 & $3-\mathrm{Cl}$ & $3-\mathrm{Cl}$ & $139-140$ & 6.95 & 6.59 & 5.63 & 5.60 & 5.8 & 6.2 \\
\hline 83 & $2-\mathrm{Cl}$ & $3-\mathrm{Br}$ & $130-131$ & 6.47 & 6.54 & 5.60 & 5.53 & 5.9 & 5.8 \\
\hline 84 & 2-Me & 4-Me & $155-156$ & 5.82 & 5.81 & 5.13 & 5.22 & 5.4 & 5.2 \\
\hline 85 & $2-\mathrm{F}$ & $4-\mathrm{Me}$ & $135-136.5$ & 6.01 & 5.75 & 5.22 & 5.19 & 5.6 & 5.5 \\
\hline 86 & $2-\mathrm{Cl}$ & $4-\mathrm{Me}$ & $134-136$ & 6.22 & 5.80 & 5.12 & 5.17 & 5.0 & 5.5 \\
\hline 87 & 2-OMe & $4-\mathrm{Me}$ & $111-113$ & 5.82 & 5.70 & 5.11 & 5.14 & 6.0 & 5.0 \\
\hline 88 & $3-\mathrm{Me}$ & $4-\mathrm{Me}$ & $123-124$ & 5.89 & 5.81 & 5.05 & 5.22 & 5.1 & 5.5 \\
\hline 89 & $3-\mathrm{Cl}$ & $4-\mathrm{Me}$ & $135.5-136.5$ & 5.92 & 5.80 & 5.40 & 5.17 & 5.2 & 5.4 \\
\hline 90 & $2-\mathrm{Me}$ & $4-F$ & $150-151$ & 6.25 & 6.62 & 5.36 & 5.48 & 6.1 & 5.6 \\
\hline 91 & $2-\mathrm{Cl}$ & $4-F$ & $143.5-144.5$ & 7.05 & 6.65 & 5.98 & 5.51 & 5.7 & 6.0 \\
\hline 92 & 2-OMe & $4-\mathrm{F}$ & $113-114$ & 6.44 & 6.33 & 5.49 & 5.20 & 5.5 & 5.8 \\
\hline 93 & $3-\mathrm{Me}$ & $4-\mathrm{F}$ & $96.5-99$ & 6.50 & 6.62 & 5.22 & 5.48 & 5.9 & 5.5 \\
\hline 94 & $3-\mathrm{Cl}$ & $4-\mathrm{F}$ & $116-117$ & 6.39 & 6.65 & 5.39 & 5.51 & 5.6 & 5.7 \\
\hline 95 & $2-\mathrm{Me}$ & $4-\mathrm{Cl}$ & $178-179.5^{q)}$ & 6.68 & 6.55 & 5.38 & 5.43 & 5.8 & 5.9 \\
\hline 96 & $2-\mathrm{F}$ & $4-\mathrm{Cl}$ & $155-156$ & 6.63 & 6.54 & 5.34 & 5.47 & 5.8 & 5.6 \\
\hline 97 & $2-\mathrm{Cl}$ & $4-\mathrm{Cl}$ & $167-168 \cdot 5^{\mathrm{m}, \mathrm{r})}$ & 6.91 & 6.52 & 5.61 & 5.37 & 5.7 & 5.8 \\
\hline 98 & $3-\mathrm{Me}$ & $4-\mathrm{Cl}$ & $114-115$ & 6.84 & 6.55 & 5.38 & 5.43 & 5.7 & 5.5 \\
\hline 99 & $2-\mathrm{F}$ & $4-\mathrm{Br}$ & $178-179$ & 6.60 & 6.56 & 5.44 & 5.47 & 5.6 & 5.9 \\
\hline 100 & $3-\mathrm{Cl}$ & $4-\mathrm{Br}$ & $160-161$ & 6.49 & 6.48 & 5.51 & 5.30 & 5.5 & 5.5 \\
\hline
\end{tabular}

a) Calculated by Eq. (5).

b) Calculated by Eq. (6).

c-m) Lit. value, respectively: $132-134^{\circ} \mathrm{C}, 78-81^{\circ} \mathrm{C}, 140-141.5^{\circ} \mathrm{C}, 127.5-129^{\circ} \mathrm{C}, 152-154^{\circ} \mathrm{C}, 115.5-$ $116.5^{\circ} \mathrm{C}, 86-88^{\circ} \mathrm{C}, 125.5-127^{\circ} \mathrm{C}, 128-130^{\circ} \mathrm{C}, 111-113^{\circ} \mathrm{C}, 164-165.5^{\circ} \mathrm{C}(\mathrm{H}$. Takahashi \& T. Suzuki : Jpn. Pat. Kokai Sho-57-139051).

$\mathrm{n}, \mathrm{o})$ Lit. value, respectively: $140.5-141.5^{\circ} \mathrm{C}, 115.5-116.5^{\circ} \mathrm{C}$ (T. Takematsu et al.: Jpn. Pat. Kokai Sho-55-104240).

p-r) Lit. value, respectively: $83.8-84.5^{\circ} \mathrm{C}, 178-178.8^{\circ} \mathrm{C}, 164-164.8^{\circ} \mathrm{C}(\mathrm{T}$. Takematsu et al.: Jpn. Pat. Kokai Sho-56-110655).

s) Not included in the correlation. 

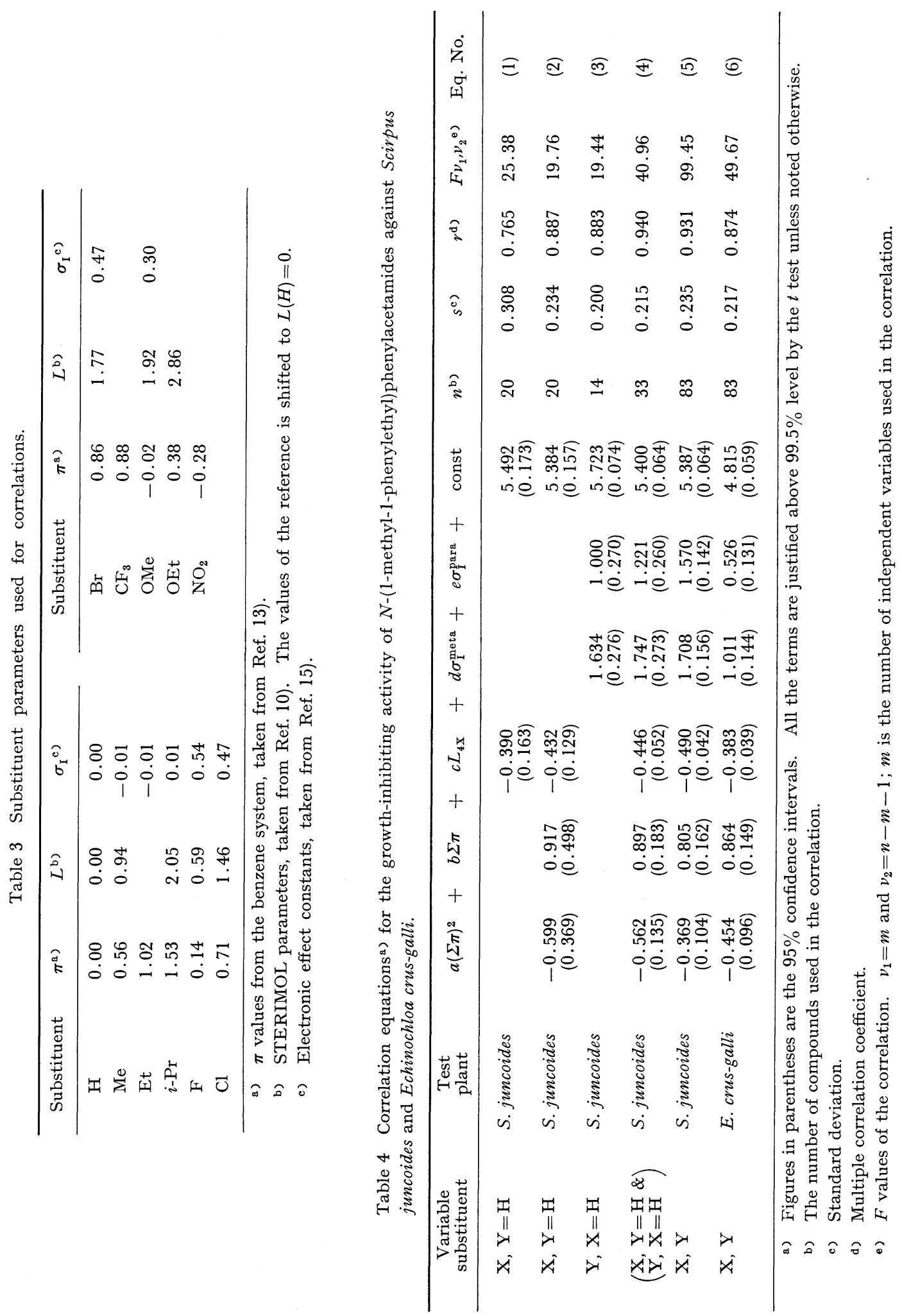
Table 5 The squared correlation matrix for variables used in Eqs. (5) and (6).

\begin{tabular}{lccccc}
\hline & $(\Sigma \pi)^{2}$ & $\Sigma \pi$ & $L_{4 \mathrm{X}}$ & $\sigma_{\mathrm{I}}^{\text {meta }}$ & $\sigma_{\mathrm{I}}^{\text {para }}$ \\
\hline$(\Sigma \pi)^{2}$ & 1.000 & 0.884 & 0.001 & 0.009 & 0.001 \\
$\pi$ & & 1.000 & 0.000 & 0.012 & 0.000 \\
$L_{4 \mathrm{x}}$ & & 1.000 & 0.022 & 0.027 \\
$\sigma_{\mathrm{I}}^{\text {meta }}$ & & & 1.000 & 0.034 \\
$\sigma_{\mathrm{I}}^{\text {para }}$ & & & & 1.000 \\
\hline
\end{tabular}

applicable for the benzene ring substituents in the amine moiety. Adding $\left(L_{4 \mathrm{x}}\right)^{2}$ and electronic $\sigma^{13)}$ terms singly or together to Eq. (2) did not significantly improve the correlation. In the case of $N$-(1-methyl-1-monosubstitutedphenylethyl)phenylacetamides (compounds 2 and 34-46), the electronic property of the benzene ring substituents in the amine moiety was important for correlating the activity variation. The Eq. (3) with the electronic effect parameter $\sigma_{\mathrm{I}}{ }^{15)}$ for substituents at the 3- and 4-positions, $\sigma_{\mathrm{I}}^{\text {meta }}$ and $\sigma_{\mathrm{I}}^{\text {para }}$, showed a good correlation. The electronic effect of the substituents at the 2-position was not significant. The use of electronic $\sigma^{13)}, \sigma^{\circ 16)}$, $F^{17)}$, or $R^{17)}$ constant instead of $\sigma_{\mathrm{I}}$ did not afford any significant improvement. Thus, Eq. (4) was derived for the combined set of both monosubstituted phenyl series of $N$-(1-methyl-1-phenylethyl) phenylacetamides against $S$. juncoides.

The derivatives having two substituents in the same phenyl group (compounds 31-33 and 47-50) showed considerably reduced activity. The activity of this type of disubstituted derivatives was not well represented by Eq. (4), the equation obtained from the monosubstituted derivatives. However, the activity of disubstituted derivatives having one substituent in the acid moiety and the other in the amine moiety (compounds 51-100) was well predicted by the equation. Finally Eqs. (5) and (6) with $(\Sigma \pi)^{2}, \Sigma \pi, L_{4 \mathrm{x}}, \sigma_{\mathrm{I}}^{\text {meta }}$, and $\sigma_{\mathrm{I}}^{\text {para }}$ were derived for 83 compounds including mono- and di-substituted derivatives against $S$. juncoides and E. crus-galli. $\Sigma \pi$ is the sum of $\pi$ values of substituents $\mathrm{X}$ and Y. The squared correlation matrix of the variables used in Eqs. (5) and (6) is shown in Table 5.

According to Eq. (5), the growth-inhibiting activity against $S$. juncoides is related parabolically to the hydrophobicity of the substitu- ents and reaches a maximum when $\pi$ is 1.09. Equation (6) shows that the activity against E. crus-galli is also related parabolically to the hydrophobicity and reaches a maximum when $\pi$ is 0.95 . These parabolic relationships seem to indicate that the compound should traverse a number of lipoidal-aqueous interfaces to reach a critical site for the activity. ${ }^{14)}$ The negative sign of the $L_{4 x}$ term in Eqs. (5) and (6) means that the activity decreases with an increase in length of the 4-substituents in the acid moiety. This result may reflect that the steric bulkiness of the 4-substituents interfares with molecular fit at the site critical for the activity. The positive sign of the $\sigma_{\mathrm{I}}^{\text {meta }}$ and $\sigma_{I}^{\text {para }}$ terms in Eqs. (5) and (6) indicates that the activity increases with an increase in electron-withdrawing effect of the substituents at the 3- and 4-positions of the benzene ring in the amine moiety. The activity variation is more sensitive to the substitution at the 3-position than at the 4-position in both plant species, especially in $E$. crus-galli. The electronic effect for the substituents at the 2-position is lacking. This result concerning the benzene ring substituents in the amine moiety does not agree with our previous report of $N$-benzylbutanamide type herbicides stating that unsubstitution is favorable for high activity.4)

The simple correlation coefficient between the activity against $S$. juncoides and that against E. crus-galli is 0.870 for 83 compounds. Moreover, Eqs. (5) and (6) have the same terms and the optimum $\pi$ value is similar between both plant species. Therefore, the mode of action of $N$-(1-methyl-1-phenylethyl)phenylacetamides against $S$. juncoides may be similar to that against E. crus-galli.

\section{Herbicidal Activity}

As shown in Table 2, $\mathrm{N}$-(1-methyl-1-phenyl- 
ethyl)phenylacetamides possess the herbicidal activity against $S$. juncoides and $E$. crus-galli in the pot tests under paddy conditions. The herbicidal activity, $\mathrm{pED}_{50}$, for 90 compounds was represented by Eqs. (7) and (8) using growth-inhibiting activity, $\mathrm{pI}_{50}$, in the vial tests.

$$
\begin{aligned}
\mathrm{pED}_{50}(\text { S. juncoides }) & \\
= & 0.517 \mathrm{pI}_{50}(\text { S. juncoides })+2.334 \\
& (0.036) \\
n= & 90, s=0.231, r=0.840, F=211.45 \\
\mathrm{pED}_{50} & (\text { E. crus-galli) } \\
= & 0.905 \mathrm{pI}_{50}(\text { E. crus-galli })+0.627 \\
& (0.059) \\
n= & 90, s=0.269, r=0.854, F=238.08
\end{aligned}
$$

In Eq. (7), the coefficient of $\mathrm{pI}_{50}$ (S. juncoides), 0.517 , is considerably smaller than 1 . This indicates that the variation in the activity against $S$. juncoides is reduced in the pot tests compared with that in the vial tests. However, the herbicidal activity in the pot tests against $S$. juncoides is correlated with the growth-inhibiting activity in the vial tests. In Eq. (8), the coefficient of the $\mathrm{pI}_{50}$ (E. crus-galli) is almost 1 and the intercept is small. This means that the herbicidal activity against $E$. crus-galli in the pot tests is similar to the growth-inhibiting activity in the vial tests.

\section{ACKNOWLEDGMENTS}

We wish to express our thanks to Prof. Toshio Fujita of Kyoto University for his invaluable suggestions. We thank Dr. Greg Goder of University of California at Berkeley for reviewing the manuscript. We also thank Messrs. Kunihiko Furuzawa, Naganori Hino, Hiroshi Matsumoto and Yoshihisa Nagano for their skilled technical assistance.

\section{REFERENCES}

1) O. Kirino, K. Furuzawa, H. Matsumoto, N. Hino \& A. Mine: Agric. Biol. Chem. 45, 2669 (1981)

2) S. Hashimoto, O. Kirino, K. Furuzawa \& H. Ohshio: J. Pesticide Sci. 8, 493 (1983)

3) O. Kirino, K. Furuzawa, C. Takayama, H. Matsumoto \& A. Mine: J. Pesticide Sci. 8, 301 (1983)

4) O. Kirino, K. Furuzawa, C. Takayama, H. Matsumoto \& A. Mine: J. Pesticide Sci. 8, 309 (1983)

5) O. Kirino, S. Hashimoto, K. Furuzawa, C. Takayama \& H. Ohshio: J. Pesticide Sci. 8, 315 (1983)
6) O. Kirino, K. Furuzawa, C. Takayama \& T. Mizutani: J. Pesticide Sci. 9, 345 (1984)

7) C. Hansch \& T. Fujita: J. Am. Chem. Soc. 86, 1616 (1964)

8) A. C. Cope, T. T. Foster \& P. H. Towle: J. Am. Chem. Soc. 71, 3929 (1949)

9) A. Kalir \& Z. Pelah: Isv. J. Chem. 5, 223 (1967)

10) A. Verloop, W. Hoogenstraaten \& J. Tipker: "Drug Design," ed. by E. J. Ariens, Vol. 7, Academic Press, New York, p. 165, 1976

11) S. H. Unger \& C. Hansch: Prog. Phys. Org. Chem. 12, 91 (1976)

12) I. Moriguchi \& T. Kanada: Chem. Pharm. Bull. 24, 1799 (1976)

13) C. Hansch, A. Leo, S. H. Unger, K.-H. Kim, D. Nikaitani \& E. J. Lien: J. Med.Chem. 16, 1207 (1973)

14) J. T. Pennistone, L. Beckett, D. L. Bently \& C. Hansch: Mol. Pharmacol. 5, 333 (1969)

15) M. Charton: "Progress in Physical Organic Chemistry," ed. by R. W. Taft, Vol. 13, John Wiley \& Sons, New York, p. 119, 1981

16) O. Exner: "Advances in Linear Free Energy Relationships," ed. by N. B. Chapman \& J. Shoter, Plenum, London, p. 1, 1972

17) C. G. Swain, S. H. Unger, N. R. Rosenquist \& M. S. Swain: J. Am. Chem. Soc. 105, 492 (1983)

\section{要 約}

\section{除草活性を有する $N$-(1-methyl-1-phenyleth- yl)phenylacetamides の定量的構造活性相関*}

桐野 修，高山千代蔵，嶺 昭彦

$N$-(1-Methyl-1-phenylethyl)phenylacetamide 誘導体法, イスホタルイ(Scirpus juncoides) 㧍よびノビェ(Echinochloa crus-galli) に対し，バイアル試験で強い生育阻害 活性を示した. 高活性発現には，フェニルアセチル基が 必要であることがわかった。酸部位およびアミン部位の ベンゼン環に種々の置換基を有するN-(1-methyl-1-phenylethyl)phenylacetamides の定量的構造活性相関を, 置 換基定数を用いた重回帰分析により解析したところ，83 個のイヌホタルイに対する活性変化は, 置換基の疎水性 に対して放物線的な関係にあることが明らかとなった。 また，酸部位のベンゼン環の 4 位置換基の長さが短いほ ぞ活性は高く, アミン部位のベンゼン環の 3 位あるいは 4 位置換基の電子吸引性が，活性を増大させることがわ かった。ノビエに対しても同様な解析式が得られた。 さ らに, バイアル試験における生育阻害活性とポット試験 に怙ける除草活性との間には，密接な関係のあることが 示された。

* $N$-Benzylbutanamides $の$ 除草活性（第 8 報） 